Projets

de paysage

\section{Projets de paysage}

Revue scientifique sur la conception et l'aménagement de l'espace

$8 \mid 2012$

Les concepteurs de jardins et de parcs japonais

\title{
The "construction" of the Greek landscape in the Hellenistic era
}

La « construction » du paysage grec à l'ère hellénistique

\section{Iliopoulou Filio}

\section{OpenEdition}

\section{Journals}

Electronic version

URL: http://journals.openedition.org/paysage/15694

DOI: 10.4000/paysage. 15694

ISSN: 1969-6124

\section{Publisher:}

École nationale supérieure du paysage de Versailles-Marseille, Institut national des sciences appliquées Centre Val de Loire - École de la nature et du paysage, École nationale supérieure d'architecture et de paysage de Bordeaux, École nationale supérieure d'architecture et de paysage de Lille, Agrocampus Angers

\section{Electronic reference}

Iliopoulou Filio, "The "construction" of the Greek landscape in the Hellenistic era", Projets de paysage [Online], 8 | 2012, Online since 24 September 2012, connection on 11 March 2021. URL: http:// journals.openedition.org/paysage/15694 ; DOl: https://doi.org/10.4000/paysage.15694

This text was automatically generated on 11 March 2021.

Projets de paysage 


\section{The "construction" of the Greek landscape in the Hellenistic era}

La « construction » du paysage grec à l'ère hellénistique

Iliopoulou Filio

\section{AUTHOR'S NOTE}

This research has been co-financed by the European Union (European Social Fund ESF) and Greek national funds through the Operational Program "Education and Lifelong Learning" of the National Strategic Reference Framework (NSRF) - Research Funding Program: Heracleitus II. Investing in knowledge society through the European Social Fund.

\section{Introduction}

\section{Scope of the Thesis}

1 Should one take into account the importance of landscape as a crucial factor in the birth and evolution of civilizations, this study will attempt to identify firstly, whether the Greek landscape was "constructed" in the Hellenistic era and secondly, the possibility of the existence of architectural principles of spatial organization which dictated the former action. It is almost certain that these principles reflected the political and social values of that historical period.

2 The aim of the research is the description of a theoretical framework regarding the perception of landscape by the societies of the past and the ways this perception defined its "construction". The methodological tools in that process will be derived from the field of landscape archaeology, on account of the idea of landscape as a " palimpsest » of human activities in the course of time. 
3 The main issue to be questioned during this process is whether one is entitled to use the term "landscape" in the Hellenistic era. Landscape is perceived in theory either as a designed condition or as the product of cultural interrelations. The connection of the ancient Greek architecture and urban planning to landscape allows for both approaches, as the studies by C.Doxiadis, G. Lavvas and V. Skully have shown ${ }^{1}$. The common conclusion of all of them is the belief that ancient Greek architecture appears to have been imposed on the existing landscape in a designed way which either completes or highlights the latter.

4 The theoretical analysis of the principles by which the Greek landscape was "constructed" in the Hellenistic era will be informed constantly throughout this process by the findings of the most thoroughly excavated town of that period, the ancient Messene. The conclusions based on the analysis of the digital model of reconstruction of the archaeological site - as it was back in the Hellenistic era - will constitute an additional measure of testing the hypothesis of this thesis.

\section{Methodology}

5 The doctorate thesis of C. Doxiadis ${ }^{2}$ will be used as the basis upon which the current thesis will develop its own arguments related to the ways the particular characteristics of the ancient Greek landscape dictated a pre-defined course through the built and unbuilt environment, which was perceived as an inseparable unity. Besides the allocation of the observer within a geomorphological context, the formation of that course suggests also the description of the entities.

6 Particular emphasis will be given on the architectural documentation of the buildings' location within a given settlement and on the existence of landmarks in the Greek landscape as fundamental elements both in the perception of the latter as well as the of the formentioned pre-defined course.

\section{The theory introduced by C. Doxiadis}

7 According to C. Doxiadis, the design of cities in the Classical and Hellenistic eras was conducted with a mathematical precision which could not be directly acknowledged by descendant generations, who knew and practiced only the rectangular system of coordinates. The design never took place on a horizontal plane but on the landscape itself, which, by definition, the formerly mentioned system cannot be related to. On the contrary, the dominant design principle was the human viewpoint, setting a system of polar coordinates according to which each point on a plane is determined by a distance from a fixed point and an angle from a fixed direction.

C. Doxiadis clearly states that « one of the most profound beliefs of the ancient Greeks was that man was the measure of all things. This concept was given visible expression in the organization of the human environment: man himself was the center and point of reference in the formation of architectural space. $»^{3}$

Space-built and unbuilt-was regarded as a unity. Buildings were situated in such a way as to integrate or accentuate elements of the surrounding landscape, resulting thus, in the perception of the city through the sequence of the organized revelation of its urban entities. 
10 What C. Doxiadis proposes is that the mathematical analysis of any given site of that era shows conformity of relationships between angles of vision and distances between buildings. The relative minor deviations in the practice of the spatial organizational model introduced by C. Doxiadis show not a flawed mathematical model but individual case studies such as the construction of a city over several centuries (extensions or differentiations depending on various demands) or even the topographical characteristics which constituted physical limitations to the application of the city plan.

11 However, there seem to be two problems with the theory introduced by C. Doxiadis, which were taken into account during this doctorate thesis, as they might be in conflict with the conclusions extracted from the study of the archaeological site of ancient Messene up to this point ${ }^{4}$. The first one is that $\mathrm{C}$. Doxiadis has based his arguments on the study of the spatial organization of the ancient city on a horizontal plane, which completely disregards the third dimension (i.e. the height of the buildings). This could either complement the theory he proposed or totally alter it. The second problem is more profound. C. Doxiadis analyses the organization of architectural space in nearly thirty sites of ancient Greece using a system of visual angles for any observer who stands on their main entrance and only there. The question is then, what happens should the observer move through these sites. Does the "harmony" which characterizes their spatial organization disappear or still remain?

\section{The concept of landscape}

\section{Space - Place (Topos) - Landscape}

12 Space constitutes an abstract concept. It is a simple container whose value is defined by its elements. Space does not have a character or particular characteristics. Its substance is merely dictated by the presence of human activities which fulfill it with forms, functions, feelings and notions, transforming it into place (topos) ${ }^{5}$.

13 Landscape reflects the cultural interpretation of "topos" either descriptively through a theoretical aspect which aims at the production of knowledge or through the practical aspect of spatial transformations. The history of mankind is interrelated to landscape, should one consider that each generation modifies, transforms and becomes attached to its surroundings in a unique way. The landscape, as a canvas of past activities oriented towards the expression and fulfillment of personal needs, is perceived as the record of collective memories whose superimposition defines its form.

14 The notion of landscape simultaneously refers to both a defined geographical unit as well as its perception by at least one person, rendering it a cultural device which selects, interprets and re-evaluates the elements of the formentioned unit. This argument is reinforced by A.B.. Knapp and W. Ashmore who state that "landscape is an entity that exists by virtue of its being perceived, experienced and contextualized by people", acknowledging thus, landscape as a cultural product ${ }^{6}$.

\section{Landscape and Architecture}

15 Architecture, impregnated with practices and symbolisms, alters concepts through various scales (spatial transformations in dimensions and uses) and thus, is constantly 
subject to evolution. The design process uses characteristics of the contemporary space in regards to the human relationships it integrates, which pre-supposes an articulation of volumes, proximities and sizes. Therefore, the form of the designed object is conceived in relation to the form of both the space it belongs to as well as the activities it allows for. If architecture produces not only designed objects but also, the architectural space which contains them, then that space is conceived as "topos". In turn, landscape constitutes then, the representation of the space where architectural creation takes place at ${ }^{7}$.

Landscape architecture is a multi-dimensional, human-centered science par excellence, since it includes the design and planning of the landscape as well as its management, under a framework of social, aesthetical and environmental values. On account of the perception of landscape as a cultural product subject to constant re-interpretation ${ }^{8}$, landscape architecture is asked to deal with an extensive variety of landscape typologies, the organization and characterization of which depends on the ways their ecological, social and aesthetical values inter-relate.

The complexity of this field of architecture relies on the combination of the formentioned variety of landscape typologies along with an analysis of landscape scales - small, medium, large -, in an attempt to meet the human needs for better living conditions in a cultural and ecological context ${ }^{9}$.

\section{The landscape of the Greek antiquity}

The landscape of the Greek antiquity consisted of both the city and its surroundings. The basic unit of the ancient Greek world, the city (polis), integrated the urban centre ("asty") and its surrounding landscape ("chora"), as well as additional smaller cities and villages, acting thus, as a unity. The mountains of Greece divide the agricultural lands into discrete geographical units, limited at all sides by sea and mountains. This topographical arrangement favors not only a sense of regionalism from a purely spatial point of view but also, an organizational pattern based on the idea that any small geographical unit is controlled/managed by the city.

The Greeks' life was closely related to landscape as a large part of the population lived in the urban centre and commuted daily in the outskirts of the city, in order to work in the farmlands. This implies that, as the agricultural production and cattle farming were the only sources of food for the urban centre, there could be no urban unit without its surrounding landscape. Y. Despotopoulos elaborates further on this idea by claiming that the landscape of the Greek antiquity can be solely perceived as the « sum » of three interrelated landscapes: the agricultural (the private - for farmers), the urban (the common) and the sacred (reserved for gods) ${ }^{10}$.

Cities in ancient Greece developed in two ways: either gradually or due to a specific historical action. In both cases, the city (polis) "produces" its own urban landscape and is, at the same time, integrated in the broader geographical landscape, being part of which both politically and financially. The city and its landscape flourish and decline together, yet there is always a visual contrast between them. The urban area has strictly defined limits, regardless of whether these take the form of defensive walls or gates. The rural population is either politically subject to the city or has political rights and these can be only exercised in the city. In any case, these differentiations, as a 
result of various historical processes, have an enormous effect on the urban environment and subsequently, on its landscape.

\section{Archaeology and landscape}

21 To archaeology, landscape has always been considered as an artifact, being either an " object " or the "subject" of studies. In the first case, archaeological research has focused on the ways each society transformed its surroundings and in turn, on how this landscape defined the human relationships and social evolution (through demographic and financial data). In the second scenario, the study of landscape aimed at the "reconstruction" of past images of the landscape as these were expressed in certain time periods. However, the complexity and multiplicity of the notion of landscape rendered both approaches one-sided and led to the creation of a new theoretical approach to landscape. This was based on the idea that the latter is a time-dependent and spatially referenced, ideologically constructed model by any given society ${ }^{11}$. Landscapes are thus, perceived and understood in many different ways, depending on the historical and social context of the viewer.

This new approach of landscape archaeology underlines the way archaeological research acts more as a generator of cultural landscapes in a broader context and less as a unified landscape which reflects a linear process of spatial transformations in the course of time.

\section{The landscape of the Hellenistic era}

\section{Historical framework}

The Hellenistic era (323 B.C.-31 B.C.) defines a new historical period during which the autonomy of individual cities of the Classical era disappeared, allowing for the will of the large kingdoms (Ptolemaic, Antogonid, Seleucid and Attalid dynasties) to diffuse the Greek civilization throughout the Middle East. As time went by, the gradual decline of the cities both from a financial and military point of view, favored the Roman influence and shortly after, the Roman dominance in 31 B.C.

\section{Architecture}

During the Hellenistic period, architecture emphasized on decoration rather than function and therefore, the Doric order was abandoned as it was considered too formal and austere. On the contrary, the architectural style of the Ionic order, being more decorative and elegant, was preferred to suit the aesthetics of the Hellenistic period.

Two new architectural elements were introduced: the arch and the dome. The extensive decorations and the game of light and shadows, in conjunction with an architectural illusionism as well as pseudoarchitectural details in the quest of a scenographic perspective, led to a confusion of proportions and ultimately in Hellenistic type deformations. 


\section{The urban landscape} "open" landscape and the walled city. Based on the archaeological data of the cities of that period, the first experience for the citizen/visitor of a city was his passing through the main gate, acting this as the threshold between the « natural/agricultural » and the «urban» landscape. 

living within the city's walls, constituted the urban landscape and it was these buildings that differentiated each city from one another. The city planning started with the street grid, followed by the allocation of the agora, the sanctuaries and the public buildings and lastly, by the allocation of the private houses.

\section{Gardens}

kind of gardens that existed in the Classical era continued to be present in the Hellenistic as well: vegetable gardens, vineyards, flower gardens, orchards, sacred gardens ${ }^{16}$. The only vegetated spaces within the Hellenistic city's walls were the sanctuaries and the public spaces such as the agora. In any case, spaces associated with vegetation were always concentrated, in order for citizens to conserve water and land area. ${ }^{17}$ Private gardens could be maintained only after their irrigation system had been properly designed for and this was made possible only after the $2^{\text {nd }}$ century A.D. ${ }^{18}$

\section{The archaeological data}

\section{The case study of Ancient Messene}

Messene is a significant Hellenistic city in terms of its size, form, and state of preservation. It possesses not only sanctuaries and public buildings, but also imposing fortifications, as well as houses and tombs. It has never been destroyed or covered by later settlements, and is located on an unspoiled inland site ${ }^{19}$.

The study of ancient Messene's landscape for this dissertation focuses on issues dealing with viewsheds through buildings, particular characteristics of the landscape related to urban life and with the allocation of volumes and functions in regard to natural resources and perspective views. To this end, it was necessary to reconstruct the ancient city of Messene as it was back in the Hellenistic era, through a digital model which would allow for a three-dimensional walk-through the city.

\section{The historical context}

Ancient Messene, the new capital of the free and independent Messenia, was built in 369 B.C. by Epameinondas from Thebes and remained as such for seven centuries. It was well known for its high social and financial status due to the "pax romana", which was established by Caesar Augustus and spanned for two centuries. The city declined in the $3^{\text {rd }}$ century A.D.

In 1895, the Archaeological Society began systematic excavations at the site under the direction of the archaeologist T. Sophoulis, followed by G. Economou in 1909 and half a decade later by A. Orlandos. In 1986 the Board of the Archaeological Society assigned the direction of the excavation project to professor P. Themelis, whose work continues to the present day with significant progress. ${ }^{20}$

\section{The quest for a new identity - The new city}

Messenians' freedom had an enormous impact on the collective memory of the new nation. The quest for political acceptance and social cohesion forced Messenians to 
present their power through an extensive building program and declare a sense of common identity which would bring together this heterogeneous population. ${ }^{21}$

\section{The character}

Ancient Messene constitutes an excellent example of a design-build-evolution process, as the city was a "programmed void space", meaning a programmatically "artificial city", designed to be self-sufficient in case of an emergency.

\section{The location}

The location of Ancient Messene is not random and Pausanias ${ }^{22}$ explains thoroughly the reasons for which this specific area was chosen. Surrounded by the mountains of Ithome and Eva, both acting as natural fortifications for the city, the new city was geographically located in the centre of the new state of Messenia. Moreover, there was a dominant water feature within the city's walls (the Klepsydra spring), feeding the fountain of Arsinoe. Finally, there was a sentimental attachment to this landscape, as it was the same area where the defeat of the Messenians had taken place in 464.B.C., after which they moved to Nafpaktos.

\section{The archaeological site ${ }^{23}$}

The archaeological site of Ancient Messene includes three types of landscape: the natural, the historical and the contemporary. The natural landscape includes the 5.000-6.000stremma valley which extends southwest of the mountains of Ithome and Eva. The historical site, integrated in the natural landscape, consists of the fortifications (including the Arcadian and Laconian gates), the acropolis on top of the Mt. Ithome and public buildings of political or religious importance (the theatre, the Arsinoe fountain house, the agora, the Asklepieion, the stadium and gymnasium). The contemporary landscape includes the adjacent villages of Mavromati and Arsinoe and the connecting routes between those two villages and the village of Meligalas through the Arcadian Gate.

\section{The monuments}



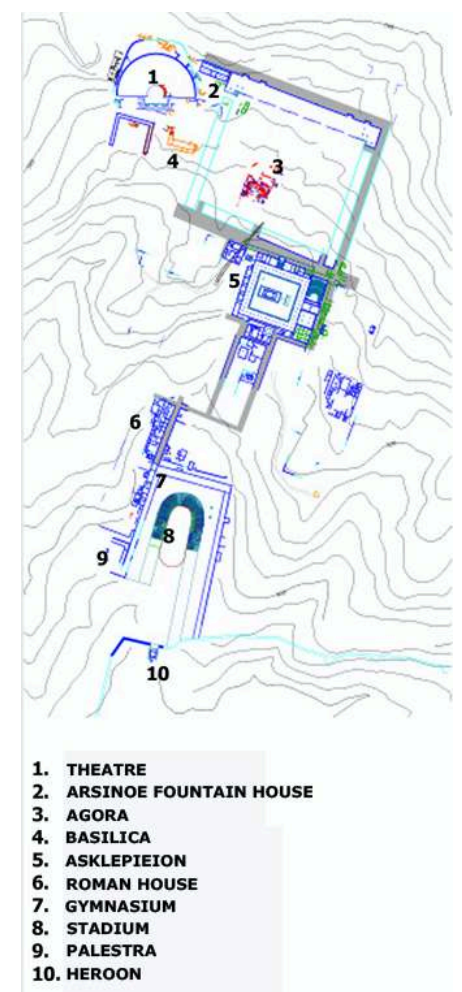

Source : Themelis, P., The Ancient Messene, Ministry of Culture, Athens: T.A.P.A. editions, 2002.

- The fortifications - The Arcadian and Laconian Gates

Ithome was the strongest natural and man-made fortress in Messenia. Remains of the walls and the square-shaped towers are evident along its entire course $(9.5 \mathrm{~km})$. The eastern Laconian Gate was destroyed in the 18th century. The western Arcadian Gate is preserved in relatively good condition and is basically, a monumental construction built of gigantic, awe inspiring limestone blocks.

- The theatre - The Arsinoe fountain house - The agora

The first monument one encounters on the way to the archaeological site is the theatre, used for large scale assemblies of political character. The theatre sits on an artificial fill supported by a strong semicircular retaining wall, the exterior of which is built in exactly the same way as the fortification walls and towers of the city.

The fountain house of the Agora was named after Arsinoe, mother of Asklepios, and received the water from the Klepsydra spring. Arsinoe fountain house includes a cistern of 40m.-long, located at a short distance from the theatre. The Arsinoe fountain house, along with all the other secular and sacred buildings of the city of Messene, were abandoned between 360-70 A.D. due to the economic decline of the Roman Empire and the final disintegration which was aggravated by barbaric raids and earthquakes.

The Agora covers a huge area of about 40 acres and is surrounded by stoas on all its four sides. Only the western part of the North stoa has been brought to light.

- The Asklepieion

Pausanias describes the Asklepieion as a museum of art works (mainly statues), rather than its more common role as a sanatorium for sick patients. It was the most prominent site in Messene and the center of the urban public life, functioning as such along with the nearby Agora. The Asklepieion consists of an almost square area (71.91 X 
$66.67 \mathrm{~m}$.), with four internal stoas opening onto the central open-air courtyard, where the imposing Doric temple of Asklepios and its large altar are located. In the last decades of the 4th century A.D. the sanctuary was abandoned.

- The stadium and gymnasium

The Stadium and Gymnasium count among the most impressive and well preserved building complexes of the site. The stadium is enclosed on its three sides by Doric stoas with most of their columns standing in place. Its colonnades belong to the Gymnasium which, along with the Stadium, formed one single architectural unit.

\section{City planning}

Figure 1. Ancient Messene's city planning

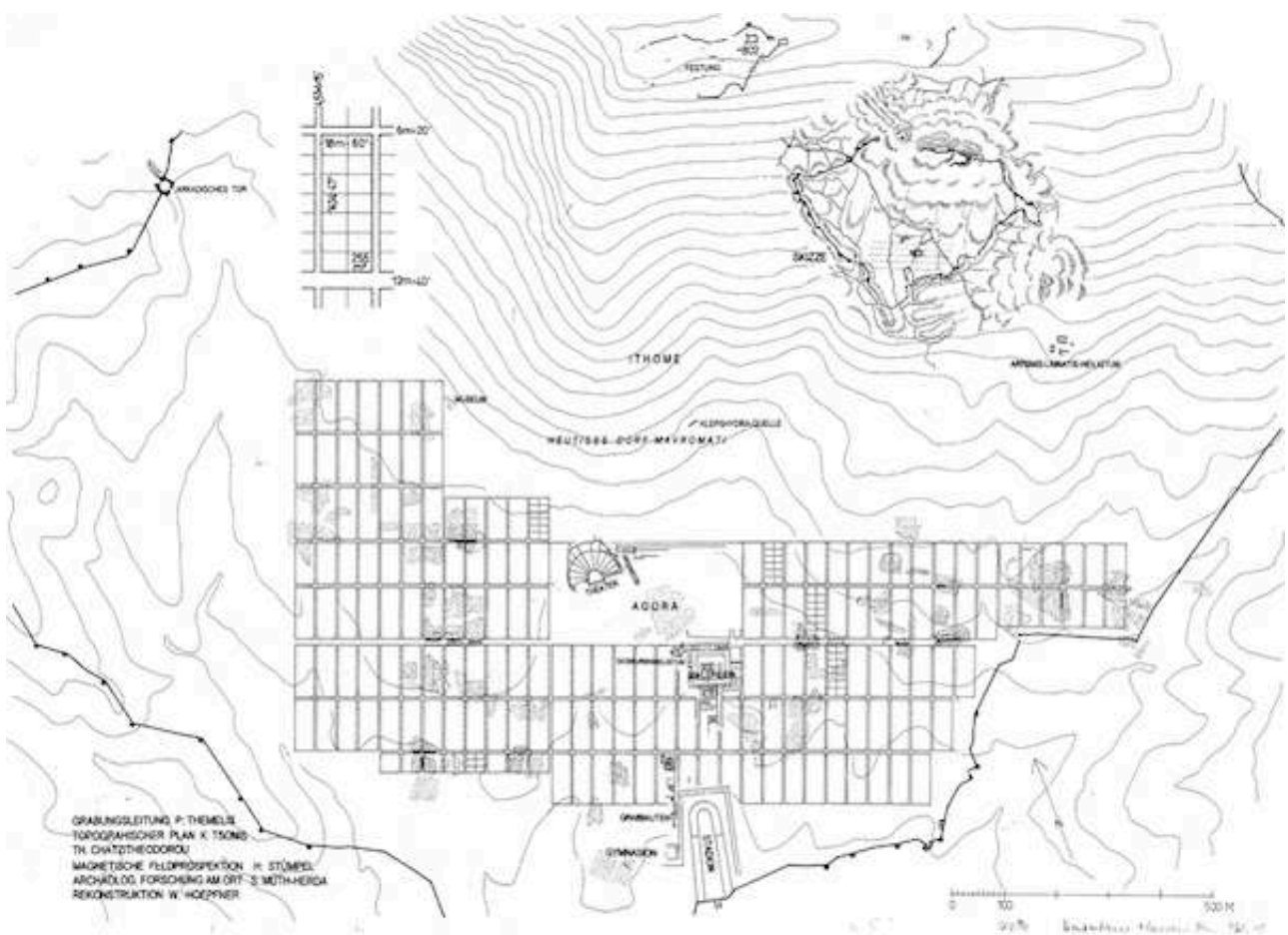

Source : Themelis, P., The Ancient Messene, Ministry of Culture, Athens: T.A.P.A. editions, 2002.

Ancient Messene's city planning followed the Hippodamian system, which was adapted in the particular geomorphological conditions of that area and thus, fully integrated into the existing landscape. This is the reason why the city's planning system constitutes an exception to the Hippodamian system's application, as the insulae vary in size. However, all buildings adapt to the insulae, with each insula including 14 houses, organized 7 by 2 parallel to each other. The various sizes of the insulae result in the creation of large building blocks, which is extremely rare for this planning system, possibly due to the rapid city planning and construction works under enormous pressure at the risk of a new war with Sparti.

\section{Conclusion}

The digital reconstruction of the archaeological site of ancient Messene offered invaluable information on the way urban planning integrates the surrounding 
landscape and as the research is still on-going, more conclusions will be derived in the future. The application of the theory introduced by C. Doxiadis failed to reveal the organization of architectural space based on certain visual angles, for reasons related to the unique history of the Messenians. A thorough study of the digital model leads to the conclusion that the criteria for the allocation of the city in the whole were more crucial than those of the individual buildings within the urban grid. The six criteria described by Pausanias are fundamental, in terms of historical and political importance and thus, they prevail in the allocation of the new capital.

As for the allocation of the buildings, there seems to be a preference for geomorphological characteristics (rocky cavity for the theatre's retaining wall) and natural resources (water spring for Arsinoe fountain house). Finally, the digital model shows that the layout of each building allows for views of the surrounding landscape, which proves the inseparable connection of the city to its surroundings.

\section{BIBLIOGRAPHY}

Books

Alcock S.E., Graecia Capta: The Landscapes of Roman Greece, Cambridge, Cambridge University Press, 1993.

Alcock S.E., Archaeologies of the Greek Past: Landscapes, Monuments, and Memories, Cambridge, Cambridge University Press, 2002.

Ashmore W. and Knapp A.B., Archaeologies of landscape: contemporary perspectives, Malden, Blackwell Publishers, 1999.

Carroll - Spillecke M., КНПОГ (der antike griechische Garten), Deutscher Kunstverlag,1989.

Carroll - Spillecke M., Earthly Paradises: Ancient Gardens in History and Archaeology, Los Angeles, J. Paul Getty Trust Publications, 2003.

Despotopoulos Y., Ideological Structures of the cities, Athens, NTUA Press, 1997.

Doxiadis C.A., Architectural Space in Ancient Greece, Cambridge, MIT Press, 1972.

Forbes H.A., Meaning and identity in a Greek landscape: an archaeological ethnography, Cambridge, Cambridge University Press, 2007.

Green P., Hellenistic History and Culture, Berkley, University of California Press, 1996.

Hodder I., Reading the past: current approaches to interpretation in archaeology, Cambridge,

Cambridge University Press, 1986.

La Rocca E., Lo spazio negato. Il paesaggio nella cultura artistica greca e romana, Milan, Electa, 2008.

Lavvas G., Altgriechisches Temenos: Baukörper und Raumbildung. Ideogramma der baulichen GruppenOrganisation, Basel, Birkhäuser Verlag, 1974.

Luraghi, N., The Ancient Messenians: Constructions of Ethnicity and Memory, New York, Cambridge University Press, 2008. 
Maria E.A., The legal protection of landscape in international, European Community and national law, Athens, Ant. N. Sakkoulas Publishers, 2009.

Miller N.F. and Gleason K. L., The archaeology of garden and field, Philadelphia, University of Pennsylvania Press, 1994.

Onians J., Art and Thought in the Hellenistic Age: The Greek World View 350-50 BC, New York, Thames and Hudson, 1979.

Osborne R., Classical Landscape with figures: the ancient Greek city and its countryside, London, Sheridan House, 1987.

Pausanias, Periegesis-Messiniaka, Athens, Cactus, 1992.

Pollitt J.J., Art in the Hellenistic Age, Cambridge, Cambridge University Press, 1986.

Skully V., The Earth, the Temple, and the Gods: Greek Sacred Architecture, New Haven, Yale University Press, 1979.

Terkenli T., The Cultural Landscape: Geographical Perspectives, Athens, Papazisis Publishers, 1996. Themelis P., Ancient Messene. Site and Monuments, Special edition of the region of Peloponnese, 1998.

Themelis P., Heroes and Hero Shrines in Messene, Athens, The Archaeological Society at Athens Library, 2000.

Themelis P., The Ancient Messene, Ministry of Culture, Athens, T.A.P.A. editions, 2002.

Vitruvius, The Ten Books on Architecture, Cambridge, Harvard University Press, 1955, transl. by Granger F.

Winter F.E., Greek fortifications, Toronto, Routledge, 1971.

Wycherley R.E., How the Greeks Built Cities, New York, Doubleday, 1969.

Zunino M.L., Hiera Messeniaka: la storia religiosa della Messenia dall'età micenea all'età ellenistica, Udine, Forum, 1997.

\section{Journals}

Alcock S. and Osborn R., 1994. “Trees in the Landscape of Pausanias' Periegesis”, in Placing the Gods: Sanctuaries and Sacred Space in Ancient Greece, Oxford, Oxford University Press, 1994. pp. 231-245.

Alcock S.E., "Minding the Gap in Hellenistic and Roman Greece", in Placing the Gods: Sanctuaries and Sacred Space in Ancient Greece, Oxford, Oxford University Press, 1994. pp. 247-261.

Calame Cl., "Gardens of Love and Meadows of Beyond: Ritual Encounters with the Gods and Poetical Memory in Ancient Greece", in Sacred Ritual Practices in Gardens and Landscapes,

Washington D.C., Dumbarton Oaks, 11, 2002. pp. 43-54.

Carroll A.B., "The Greeks and the Environment”, in Teaching Business Ethics, Springer, Vol.4:1, 2000 , pp. 109-110.

Müth S., "Their own ways. Topography and town layout of Messene in the Late Classical and Hellenic periods", in Internationale Archäologie IA99, Berlin, Rahden/Westf, 2007. pp. 258-285, 305-306.

Osborne R., "Classical Greek Gardens", in Garden History: Issues, Approaches, Methods, Washington, J. D. Hunt,1992. pp. 373-391. 
Roger A., “Was Ancient Greece a Landscape society?”, in Art and Landscape, Athens, 2001. pp.

44-54.

Themelis P., "The economy and society of Messenia under Roman rule", in Meletemata XX: Roman Peloponnese III. Society, economy and culture in the imperial roman order: continuity and innovation, Athens, 2010. pp. 1-31.

Ucko P. and Layton R., “The archaeology and anthropology of landscape: shaping your landscape", in One world archaeology, London, Routledge, 1999, Vol.30. pp. 104-110.

Image credits: Themelis P., The Ancient Messene, Ministry of Culture, Athens, T.A.P.A. editions, 2002.

\section{NOTES}

1. Doxiadis C.A., Architectural Space in Ancient Greece, Cambridge, MIT Press, 1972 ; Lavvas G., Altgriechisches Temenos: Baukörper und Raumbildung. Ideogramma der baulichen Gruppen-Organisation, Basel, Birkhäuser Verlag, 1974 ; Skully V., The Earth, the Temple, and the Gods: Greek Sacred Architecture, New Haven, Yale University Press, 1979.

2. Doxiadis C.A., Architectural Space in Ancient Greece, op. cit., 1972.

3. Ibid., p. 20

4. As this thesis is still on-going and more results are expected, this cannot be yet a solid argument.

5. Terkenli T., The Cultural Landscape: Geographical Perspectives, Athens, Papazisis Publishers, 1996.

6. Ashmore W. and Knapp A.B., Archaeologies of landscape: contemporary perspectives, Malden, Blackwell Publishers, 1999.

7. Maria E.A., The legal protection of landscape in international, European Community and national law, Athens, Ant. N. Sakkoulas Publishers, 2009.

8. Hodder I., Reading the past: current approaches to interpretation in archaeology, Cambridge, Cambridge University Press, 1986.

9. Maria E.A., The legal protection of landscape in international, European Community and national law, op. cit.

10. Despotopoulos, Y., Ideological Structures of the cities, Athens, NTUA Press, 1997.

11. Ucko P. and Layton R., "The archaeology and anthropology of landscape: shaping your landscape", in One world archaeology, London: Routledge, 1999, Vol.30. pp. 104-110.

12. Alcock S.E., Graecia Capta, The Landscapes of Roman Greece, Cambridge, Cambridge University Press, 1993.

13. These included the principles of isonomy (equality before the law), of isopolity (equal civic rights) and of isomoiria (equal share in landownership).

14. Themelis P., Ancient Messene. Site and Monuments, Special edition of the region of Peloponnese, 1998.

15. Vitruvius, The Ten Books on Architecture, Cambridge, Harvard University Press, 1955, transl. by Granger F.

16. Winter F.E., Greek fortifications, Toronto, Routledge, 1971.

17. i.e. vegetation around sanctuaries providing shade during ceremonies.

18. Birge D. E., Sacred Groves in the Ancient World, Berkeley, University of California, 1982, Ph.D. diss.

19. Carroll - Spillecke M., КНПО (der antike griechische Garten), Deutscher Kunstverlag, 1989.

20. Themelis P., The Ancient Messene, Ministry of Culture, Athens, T.A.P.A. editions, 2002.

21. Ibid. 
22. Alcock S.E., Archaeologies of the Greek Past: Landscapes, Monuments, and Memories, Cambridge, Cambridge University Press, 2002.

23. Pausanias, Periegesis-Messiniaka, Athens, Cactus, 1992.

\section{ABSTRACTS}

In recognition of the importance of landscape as a crucial factor in the birth and evolution of civilizations, the current on-going doctorate thesis examines the way the Greek landscape was constructed - if at all - in the Hellenistic era, claiming that its design was based on certain architectural principles which reflect the political and social values of that historical period. The doctorate thesis of Constantinos A. Doxiadis, "Architectural Space in Ancient Greece", will be used as the basis upon which the current research will develop its own arguments related to the ways the particular characteristics of the ancient Greek landscape dictated a pre-defined course through the built and unbuilt environment, which was perceived as an inseparable unity. The theoretical analysis of the principles by which the Greek landscape was "constructed" in the Hellenistic era will be informed constantly throughout this process by the findings of the most thoroughly excavated town of that period, the ancient Messene.

\section{INDEX}

Mots-clés: archéologie du paysage, prédéfini cours, ère hellénistique, Messène ancienne, la perception du paysage

Keywords: landscape archaeology, pre-defined course, Hellenistic era, ancient Messene, landscape perception

\section{AUTHOR}

\section{ILIOPOULOU FILIO}

Architect_A.U.Th., Landscape Architect_MLA Harvard University, PhD Candidate_N.T.U.A., Scholar of the Greek Ministry of Education, Lifelong Learning and Rel. Affairs (European Social Fund NSRF 2007-2013 - Hrakleitos II)

iliopoulou.filio[at]gmail[dot]com 